\title{
Advancing a Distributive-Bargaining and Integrative-Negotiation Integral System: A Values-Based Negotiation Model (VBM)
}

\author{
Ivan Gan \\ Department of Communication, Texas A\&M University, College Station, TX 77843, USA; gan@tamu.edu
}

Received: 21 July 2017; Accepted: 21 September 2017; Published: 29 September 2017

\begin{abstract}
The proposed values-based negotiation model (VBM) agrees with and extends principled negotiation's recognition of personal values and emotions as important negotiation elements. First, building upon Martin Buber's existentialist treatment of religion and secularism, VBM centers on religion as one of many possible sources of personal values that informs respectful and mutually beneficial interactions without needing one to necessarily be religious. Just as one need not be a Buddhist or a Hindu to practice yoga, negotiators of any theological outlook can profit from a model grounded in broad, common tenets drawn from a range of organized religions. Second, VBM distinguishes feelings from emotions because the long-lasting and intrinsically stimulated effects of feelings have greater implications on the perception of negotiated outcomes. VBM negotiators view negotiations as a constitutive prosocial process whereby parties consider the outcome important enough to invest time and energy. Negotiators who use VBM appeal to the goodness of their counterparts by doing good first so that both parties avoid a win-lose outcome. This counterintuitive move contradicts the self-centered but understandably normal human behavior of prioritizing one's own interests before others' interests. However, when one appeals to the goodness of one's Buberian Thou counterparts, he or she stimulates positive emotions that promote understanding. Third, VBM provides a framework that draws upon an individual's personal values (religious or otherwise) and reconfigures the distributive-bargaining-and-integrative-negotiation distinction so that negotiators can freely apply distributive tactics to claim maximum intangible and tangible outcomes without compromising on their personal values or valuable relationships.
\end{abstract}

Keywords: conflict; negotiation; personal values; prosocial; relationships

\section{Introduction}

"A mature person is one who does not think only in absolutes, who is able to be objective even when deeply stirred emotionally, who has learned that there is both good and bad in all people and in all things, and who walks humbly and deals charitably with the circumstances of life, knowing that in this world no one is all knowing and therefore all of us need both love and charity."-Eleanor Roosevelt

Negotiations are a salient feature of many human interactions that typically take place in the context of past, present, or future relationships (Lewicki et al. 2015; Rubin and Swap 1994). Opinions and perceptions undergirding past business negotiations set up expectations for future interactions, which become reinforced over the course of repeated interactions (Greco et al. 2011). Consequentially, the ways in which negotiators relate to each other-may it be professional and / or personal relationships-influence the communicative process of reaching an agreeable outcome. Although close relationships are definitely not free of conflicts, respectful relationships can help soothe negative feelings between negotiators and remind them of the meaningful purpose of reaching 
negotiated outcomes (Lewicki et al. 2015). Relationships are therefore one of the emphases of integrative negotiation.

Despite the significance of negotiations as a means to manage conflict as well as relationships (Lewicki et al. 2015), some people disdain negotiations because they view the process as one that compromises morality and values (Benjamin 1998) while others may avoid confrontations altogether because of a prevailing perception that conflicts are fundamentally bad (Bush and Folger 2005). Positions such as these may have been informed by unpleasant experiences with unyielding distributive bargainers but such positions are not and should not be the dominant approach or attitude toward how one negotiates differences. By choosing not to actively negotiate, individuals are implicitly negotiating using the Dual Concerns Model's avoidance style (Kilmann and Thomas 1977). By choosing avoidance, individuals are at best maintaining the status quo (or worse, prolonging or aggravating the situation). While avoidance may sometimes be the best or only option, it certainly leaves unexamined and unclaimed value (both tangible and intangible outcomes) at the bargaining table. In other words, the avoidance style oftentimes concedes tangibles and intangibles unnecessarily. Creating and claiming maximum value do not necessarily compromise one's morals or values. The pertinent point is how and to what end does one negotiate. If negotiations revolve around relationships, personal values must have a seat at the (bargaining) table because personal values frame how individuals manage their relationships and conflicts (Bush and Folger 2005; Lewicki et al. 2015), Therefore, a theory-based conflict management model that draws upon personal values will advance negotiation theory and practice.

Emotions are a significant element for consideration in every negotiation (Der Foo et al. 2004; Fisher and Ury 1981). Neurologists have underscored the important relationship between emotions and moral decision-making (Bechara 2004; McCormick et al. 2017), giving management scholars a vital insight into the irrational and nonlinear process of human decision-making (Adler et al. 1998; Ariely 2008; Robinson et al. 2017). However, prevailing negotiation theories and models do not thoroughly explore how personal values affect emotions' effect on negotiations. Furthermore, emotions are distinct from feelings. On the one hand, emotions arise from external stimuli (Damasio and Carvalho 2013); for instance, one may experience pain upon hearing that her investments have unexpectedly depreciated. On the other hand, feelings refer to "mental experiences of body states" (Damasio and Carvalho 2013, p. 143); for example, one may also experience pain but this time due to physical fatigue. Both emotions and feelings can trigger pain, but emotions come from extrinsic factors whereas feelings come from intrinsic physical factors pertaining to the individual. This distinction implies that feelings have longer-term effects than emotions. Unlike Fisher and Ury's model, VBM is concerned about feelings and not emotions because one's feelings about a negotiation are self-triggered while emotions require an other-triggered stimulus. Everyone has to live with the consequences of any negotiation, experiencing feelings such as the "buyer's remorse" or the "winner's curse," especially since the stimuli (potentially arising from personal values) that can evoke feelings are more readily present than stimuli that evoke emotions. Because negotiators' feelings affect their moral judgment and their assessment of the negotiation process and outcome (Cameron et al. 2013; Lewicki et al. 2015), feelings embody an important facet of negotiations research distinct from emotions that require greater scholarly attention.

Toward that end, the academic distinction between distributive bargaining and integrative negotiation does not reflect how this communicative practice unfolds in real life. Indeed, many conflicting goals appear mutually exclusive at first instance and mislead negotiators into prematurely categorizing a situation as distributive or integrative. Thus, with the objective of managing conflicts from a values-based perspective, values-based negotiation model (VBM) promotes negotiations as a prosocial discourse.

The development of VBM builds upon Martin Buber's notions of I-It and I-Thou. Buber's notion of existentialism makes religion practical because the cognition of one's existence informs how one treats others. This thesis of Buber's grounds my work as one that makes religious tenets useable by negotiators of any theological outlook - this point supports the very heart of VBM as a 
relationship-focused and values-based model. Alternatively, religions can be perceived as theories or philosophies for those who do not believe in them. One need not be religious to apply those tenets to his or her life. Moreover, VBM does not proselytize any particular religion; instead, VBM draws prosocial attributes from several organized religions. Therefore, VBM offers a parsimonious negotiation model that is stripped of the faith element of those religions but retains the social interaction element.

Three enduring theories-attachment theory, attribution theory, and goals-plans-action theory-provide VBM with its theoretical structure. I will introduce readers to examples that call for a VBM approach and how VBM taps into negotiators' personal values as a negotiation resource. Apart from its practical utility, VBM provides scholars with a parsimonious framework for future theorizing of and research on negotiations as a communicative behavior (Gan 2014).

\section{Buber: VBM's Inspiration}

VBM's ontological foundation adopts Buber's notion of dialogue in human relationships, namely I-It and I-Thou. Buber preferred I-Thou because he valued authentic relationships that openly and willingly accept the other-the openness provides a platform for dialogical communication. Buber (1952) prompted reflections on individuals' place in the world in relation to other human beings-pertinent thoughts that arose from the context of his Jewish upbringing and the racial and religious lies that sparked World Wars I and II. While Buber's musings were grounded in religious thoughts, his thesis on the religious life underscores important philosophical questions pertaining to how one cognizes his or her existence. Thus, Buber viewed dialogue as the authentic presences of individuals who not only respond to confrontations promptly and directly but who also genuinely accept one another.

I-Thou represents a form of hospitality - a selfless gesture of giving without ulterior motives necessarily. The degree of reverence that one accords to others sets the It and Thou distinction. The treatment of others as Thou — that is, a reverent peer-means that one recognizes the needs within him or herself that he or she also sees in others and offers what he or she has as a generous act of service. As Buber (1958) put it, "The Thou meets me through grace-it is not found by seeking" (p. 11). That wisdom signifies that a party becomes the Thou in a conversation because someone else treats him or her as a person and not an object. Similarly, if Person A were to treat Person B as an object then he or she becomes an object as well because Person A will not recognize situations where Person B treats him or her as a Thou. Such interactions remove the inherent humanness within the persons of oneself and the other (Buber 1952). Note that there are times where non-relational transactions are preferred or necessary to avoid information overload and to keep life more manageable. For example, I could still transact cordially without having to spend an inordinate amount of time exchanging interpersonal details with the clerk at a gas station located in a remote town that I will most likely never drive through again. Nevertheless, I-Thou embodies a reciprocal exchange whereby interactants treat each other as individuals connected in interdependent relationships. Therefore, the I-Thou approach facilitates dialogue and builds relationships.

Buber's preferred notion of dialogue, I-Thou, emphasizes the humanness of the other. As Stewart et al. (2004) wrote, "Buber argued that it is not the case that humans exist and then enter into relations but that, as we relate and in our relating, our humanity is realized" (p. 28). When one views the other as a person and not an object, one considers the other as a person who is just as human as the individual him or herself. Consequently, the individual should also realize that the other possesses human qualities such as emotions and feelings. Since the other emotes-just about every human does-the individual should treat the other as a peer in most instances. The treatment of the other as a peer elevates the level of communication whereby the dialogue embodies mutual respect, which opens up pathways toward mutual understanding. Therefore, because I-Thou recognizes the human side of the other, I-Thou values the genuineness in authentic interpersonal relationships.

On the other hand, the I-It relation broadens the gulf between interactants and perpetuates a zone almost devoid of emotions. In that sense, the I-It relation does not stimulate a sustainable dialogue 
that can resolve conflict. I-It creates a vacuum without positive emotions and perpetuates negative emotions because one can easily disregard the feelings of the other. Such individuals view others as objects with whom they communicate as a means to an end. When one does not care about the other's feelings, one will easily fall into the trap of feeling superior to the other. That false elevation of superiority magnifies the power differential between interactants and makes dialogue less conducive. Therefore, emotions can have a negative impact in the I-It configuration.

Within this Buberian framework, emotions serve a positive dialogical function of fostering relationships and in promoting the prosocial value of treating the other as a Thou. In I-Thou settings, dialogues imbued with positive emotions help bridge differing perspectives. Hence, emotions enhance the dialogic exchange in I-Thou configurations-the basis that sustains interpersonal relationships and positive feelings.

\subsection{Why Do Negotiators' Feelings Matter to VBM?}

Scholars who study negotiations as constitutive events between disputants have primarily focused on resolving incompatible goals (see Gan 2014; Olekalns and Smith 2013). That means that negotiations are meaning-making interactions bounded by the network of actors involved. This observation sets up the premise for the present essay: A more authentic appreciation of the spirit of integrative negotiation recognizes the long-lasting and intrinsically stimulated feelings that negotiated outcomes have on negotiators and their constituents. Those sentiments have implications for their current and future relationships with one another (Fisher and Ury 1981; Lewicki et al. 2015) as well as provide insights into the subjective values that negotiators hold dear in negotiations (Curhan et al. 2006). As Fisher and Ury (1981) advised, negotiators are people who "have emotions, deeply held values, and different backgrounds and viewpoints" (p. 21). Hence, feelings shed light on the subjective and personal values important to the negotiators.

Conflict literature predominantly underscores the challenges of studying emotions in negotiations and has focused considerably less on how negotiators feel about negotiation models in relation to their personal values (Barry and Fulmer 2004; Harinck and Van Kleef 2012; Leon-Perez et al. 2010; Ome 2013; Reb 2010; Van Kleef et al. 2006; Xie and Zhou 2012). Indeed, feelings (as a construct) have received less scholarly attention in general (Greco et al. 2011). Feelings deserve greater attention from scholars of negotiations in general and organizational behavior scholars of leadership in particular. Thus, VBM offers an approach that leaves involved parties feeling they have reasonably received the best intangible and tangible outcomes without having to compromise on their personal values or valuable relationships.

\subsection{Why Should Negotiators Care about Interpersonal Relationships?}

Conflict management is a particularly important set of skills for leaders and organizational life (Bass and Bass 2008), especially for managers who have to manage personnel relations. Indeed, leadership scholarship acknowledges that scholars and practitioners who study interpersonal conflict should first understand human communication (Northouse 2015). As an integral social activity of human communication, conflict management constitutively constructs meaning through verbal and nonverbal symbols. The exchange of those symbols constitutes negotiations.

The Buberian view of respecting others as peers, who can and do emote, has lasting implications for negotiations research. Negotiators who can conceptualize and practice this paradigm will have a different approach toward negotiations and the interests at stake. Fundamentally, the Buberian negotiator will realize that any single present negotiation only represents an episode of a long-term dialogue with his or her counterpart. To that end, the development of VBM makes this Buberian principle practical and practicable.

While many conflict management researchers have studied negotiations that happen at the bargaining table, little scholarship has given attention to the relationship-much less the interpersonal relationships involved-among negotiators and their constituents. Since integrative 
negotiation helps build trust among negotiators (Young and Durwin 2013), VBM underscores the key benefit of viewing interpersonal relationships as the cornerstone that cements the integral distributive-bargaining-and-integrative-negotiation system.

Consider this scenario: Sam is a new management trainee who has an ambitious-albeit risky - proposal for his division. Sam's supervising manager, David, sees the potential in this proposal but suspects that their risk-adverse division director will not give the final approval. David therefore finds himself caught between Sam and the division director because David has a professional duty of mentoring Sam while ensuring that he appropriately supports his division director. Not only so, David also upholds a work ethic inspired by his personal value of doing right by others. When David attempts to win the division director's approval for this promising proposal, Sam is David's constituent; when David returns to Sam to negotiate with him as to whether he will scale down the proposal, the division director becomes David's constituent. This simplistic example demonstrates how David simultaneously deals with constituents who used different strategies on him-Sam most probably applied distributive tactics because he cares more about advancing his career whereas the division director might frame the situation using an integrative approach that emphasizes the importance of maintaining their division's market share. David has to take into account the interests of both Sam and the division director as well as his interpersonal relationships with each of them. Nevertheless, as David ascertains the best way that will meet and advance the interests of Sam and the division director, he needs a model of managing this conflict that resonates with his values-based work ethic as well as respectfully treating them as individuals and not objects.

The heart of relationship-informed negotiations centers on personal values-the motivational antecedent. Hence, the goal of realizing a Buberian version of relationship-informed and values-based negotiation becomes practical and achievable when negotiators behave in a prosocial manner.

\subsection{Why Theorize an Integral Values-Based Negotiation System?}

VBM reconfigures the distributive-bargaining-and-integrative-negotiation distinction so that negotiators can freely apply distributive tactics within the limits that their personal values will permit while engaging in the integrative process of cultivating enduring relationships. VBM negotiators view negotiations as a constitutive prosocial process whereby parties consider the outcome important enough to invest time and energy, recognize that their counterparts can satisfy their goals, and create the need to cultivate interpersonal relationships for mutual benefit. Negotiators who mindfully demonstrate prosocial characteristics achieve greater joint-gains than egocentric negotiators (Tzafrir et al. 2012). Moreover, negotiators who think from the other's perspective exhibit less egocentrism, which in turn reduces biased perceptions and increases constructive exchanges in the negotiation process (Chambers and De Dreu 2014). Consequently, VBM negotiators will more likely achieve their respective goals while remaining true to their personal values. For the purposes of this essay, personal values refer to the motivators of prosocial behaviors as drawn from the psychology of religion literature.

\subsection{Why Create a Negotiations Model Fused with Religious Tenets?}

Some may contend that religion has caused many conflicts and ask why introduce religion into this essay. My thesis does not dismiss those perspectives. Rather, as other scholars such as Kuttner (2012) will agree, I posit that negotiators can tap into religious tenets as a conflict management resource. As a resource, religion can exacerbate or alleviate conflicts just as fire can cause different outcomes depending upon who uses it and for what purpose. Thus, religious prosocial attributes have the potential of informing negotiation processes that align close to one's conscience.

Take a couple of nonreligious scenarios for consideration, as they illuminate how prosocial behaviors contribute to negotiation outcomes. In this first scenario, an overworked secretary negotiates with her manager about taking a day off. Many managers will agree that at the heart of such a negotiation is not about the day off but rather a communicative opportunity where the secretary and 
her manager talk about their needs and expectations of each other; this opportunity, based on their present relationship, can change how they will relate to each other in the future (see Lewicki et al. 2015). One approach of sustaining this relationship requires a prosocial exchange of acceptance between the individuals' needs. In this example, it will benefit the secretary and her manager if they strategize their communication using VBM. Juxtapose the earlier scenario with this scenario whereby the manager herself negotiates with a vendor who has not been forthcoming about his product's pricing with the manager's secretary-a prosocial gesture of the manager for standing up for her new secretary. The manager will probably negotiate for the best deal with little to no interest in cultivating a relationship with the vendor, as her way of stating the time-sensitive nature of the transaction. This kind of negotiation typically neither violates one's personal values nor undermines social harmony. Indeed, one may argue that the manager negotiates in her self-interest of keeping the more valued relationship with her secretary than with the vendor. While the second scenario differs from the first, the second scenario may also call for VBM even though the nature of that transaction does not profit a long-term perspective (perhaps the vendor may disagree, albeit a one-sided perception). Nevertheless, the manager may reciprocate the vendor's intention of establishing a relationship and still apply distributive bargaining tactics.

The above manager-secretary relationship provides the basis for a dialogue for sustained benefit for both parties. Negotiators with an authentic interpretation of integrative negotiation will view their counterparts as people with whom they cultivate interpersonal relationships, yet in integrative situations lie also moments for distributive tactics. The distinction between distributive and integrative tactics blurs and the practical benefits of VBM materialize when negotiators conduct themselves in a prosocial manner that is consistent with their conscience.

\section{Rationale and Assumptions: The Connection between Interpersonal Communication and the Psychology of Religion (as One of Many Possible Sources of Personal Values)}

Building upon Martin Buber's existentialist treatment of religion and secularism, VBM centers on religion as one of many sources of personal values that informs respectful and mutually beneficial interactions without needing one to necessarily be religious. Negotiators of any theological outlook can profit from a model grounded in tenets drawn from a range of organized religions, just as one need not be a Buddhist or a Hindu to practice yoga.

The religious dimension of human psychology has become a legitimate psychological research endeavor because "if it is to account for the beliefs and explanations of real people, it cannot omit consideration of religious claims" (Proudfoot and Shaver 1975, p. 328). Religious practices, as a form of personal values, profoundly influence negotiators (Ashwell 2003; Shakun 2006), even in nonreligious contexts and individuals. Hence, religion-informed personal values as a practical conflict management resource promotes prosocial behaviors and negotiated outcomes that align with one's conscience.

Developmental psychologists have argued that children's theistic perspectives come from culture (Banerjee and Bloom 2013). Followers of most deity-based belief systems conduct themselves in prosocial and virtuous ways because of their own accord and/or because they have internalized the belief that their respective deities are watching them (Ahmed and Salas 2011; Clobert and Saroglou 2013; Gervais and Norenzayan 2012; Purzycki 2013; Shariff and Norenzayan 2007). Some may also view dreams and hallucinations as religious inspirations or explanations to life experiences (Taves 2008). As such, that might explain why most people adopt a religious framework to make sense of life (Spilka et al. 1985).

Personal values inform personal identities and ethics (Lewicki et al. 2015). Given the opportunity, most people try to practice their personal ethics through prosocial behaviors. Since belief systems offer different frameworks to understand the purpose and meaning of life (Farias et al. 2013; Hicks and King 2008; Willard and Norenzayan 2013), and since humans are generally concerned about morality regardless of their beliefs on afterlife (Jong et al. 2012), belief systems shape the personal values that one holds dear. Thus, belief systems define the purpose and frame perceptions surrounding negotiations. 
One's belief system shapes her or his perspective of reality (Farias et al. 2013; Hicks and King 2008). Individuals have subjective outlooks that frame subjective realities. Through their individual subjective realities, individuals make sense of phenomena as constructed objectivity (Lee 2009). In doing so, individuals square their versions of objectivism with their ethical beliefs and they may view other people's moral beliefs as less objective than theirs (Goodwin and Darley 2008, 2012). Individuals "who grounded their ethical beliefs in the notion of a divine being" were more likely to have an objective, as opposed to subjective, view toward ethics (Goodwin and Darley 2008, p. 1359). Furthermore, religious individuals generally view the world as nonrandom and structured because they believe that their gods predestine the way they act and feel (Laurin et al. 2008; Mallery et al. 2000). Thus, the attachment that religious individuals have to their gods operates as a form of psychological security.

Since religiosity also has a positive effect on mental health (Flannelly and Galek 2010; Reinert et al. 2009; Stroope et al. 2013), those whose belief systems expect prosocial behaviors should forgo petty bargaining because a higher power will take care of the outcome and the future; they should instead focus on strengthening relationships and treating the other as a Thou. The assurance from one's belief system will likely stimulate positive emotions, which typically encourage cooperation during negotiations (Van Kleef et al. 2006).

\section{Rationale and Assumptions: The Connection between Interpersonal Communication and Cognition}

VBM helps negotiators achieve their negotiation goals and cultivate enduring interpersonal relationships because religious practices interact and relate to other religions (Bretfeld 2012). Just like any other forms of culture, individuals socially construct their own belief systems by drawing from organized religion/s. Benefiting from research at the intersection of cognition and social behavior (Churchland 2008), VBM posits that belief systems also affect individuals' attention span and cognition (Colzato et al. 2010)—two important factors that affect negotiations. Thus, belief systems help negotiators make purposeful decisions as they cognize their values and needs with their constituents' values and expectations.

Negotiators who use VBM appeal to the goodness of their counterparts by doing good first so that both parties avoid a win-lose outcome. This counterintuitive move contradicts the self-centered but understandably normal human behavior of prioritizing one's own interests before others' interests. Integrative negotiation is not a zero-sum game where quantifiable outcomes determine the success of the negotiation.

Although religious individuals generally thank their deities for favorable situations, the same individuals usually refrain from assigning blame on their deities for unfavorable situations (Spilka and Schmidt 1983). If one party feels that he or she has "lost" in the negotiation, the feeling of being the "loser" usually creates emotional dissatisfaction and he or she may seek some form of restitution (legal or otherwise), which does not produce an integrative outcome much less an environment that cultivates interpersonal relationships. Since feelings affect moral judgments (Cameron et al. 2013), including those entirely unrelated to the negotiation, one should bear in mind that even the most religious or moral individuals can potentially turn hostile if they feel threatened or become fixated on negative thoughts.

Expanding on the argument from the previous two paragraphs, the findings of Cameron et al. (2013) contrast with another study on religious individuals: Individuals who profess a deity-based belief rely more on their deities during moments of anxiety because they believe in a God who is in control (Laurin et al. 2008). The Cameron et al. (2013) and Laurin et al. (2008) findings suggest that individuals_-both genuine and nominal believers-who profess deity-based beliefs and experience negative emotions will seek justice for themselves instead of waiting on their deities to give them what they believe they should receive. Therefore, appealing to the goodness of one's Buberian Thou counterparts by doing good to them first may sound radically counterintuitive yet it stimulates positive emotions, which in turn will bring about understanding and sustain dialogue for conflict resolution. 
When people feel threatened or fixate on negative thoughts, their emotions rule their minds. They may justify their reaction as a completely objective, rational, and even mature response. Negotiators who appreciate the true value of enduring outcomes for themselves and their constituents recognize the bigger purpose of life and will avoid a win-lose outcome to the point of conceding certain immediate losses by way of practicing hospitality and taking the I-Thou view. Hence, a key subconscious goal is how negotiators square their negotiation strategies with their personal values.

\section{The Model}

Belief systems are an important aspect of one's identity and personal ethics (Lewicki et al. 2015). Three theories informed the creation of VBM: attachment theory, attribution theory, and goals-plansaction theory. VBM (see Figure 1) also takes into account faith-based scholarship on conflict management and posits that every human is essentially either overtly or covertly good-natured. The four VBM elements, and their accompanying considerations before and during negotiations, are:

(1) What are my values?

(2) What do I need from the other party?

(3) How do I build a relationship?

(4) How do I appeal to the other party's goodness and remain true to my values?

\section{Preparation for the negotiation}

What are my values, need/s, desired relationship, and appeal?

\section{During the negotiation}

(1) Cycle through my values, need/s, desired relationship, and appeal; and

(2) Can I arrive at a negotiated agreement within the mutually agreed deadline or timeframe?

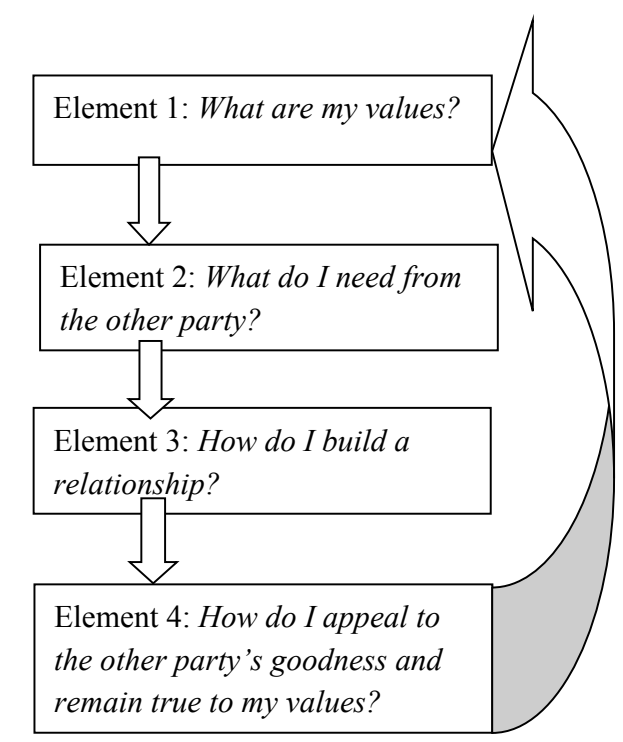

Figure 1. Values-Based Model.

\subsection{First Element (Pre-Negotiation): What Are My Values?}

Attribution theory undergirds this element. This theory is grounded in the notion that individuals make sense of events by finding explanations as to why things happened in a certain way or why people did certain things (Weiner 1985). Put differently, people generally seek cause-effect relationships to contextualize their perceptions of responsibility (Martinko et al. 2006). People may also use emotions and feelings as sense-making data. Management scholars have recently applied attribution theory 
to explain how negotiators attributed perceived threat and cooperativeness to their counterparts' emotions (Hillebrandt and Barclay 2017), how individuals' varied attributions of supervisor behavior led to different emotions and behavioral responses (Oh and Farh 2017), and how the attribution of external or internal locus of control could explain stakeholders' perception of foreign organizations (Crilly et al. 2016). The premise that VBM draws from attribution theory is that people square their experiences or proactively anticipate future encounters using resources, such as personal values, that they currently have.

This pre-negotiation element primes negotiators' moral realism, which cognitively prepares them toward a collectivist attitude and frames their thoughts in relation to their moral beliefs (Young and Durwin 2013). Christian scholarship has looked at how disputants who share the same faith can resolve their conflict not in a passive fashion but in a way that will honor their faith (Ennis 2008). Similarly, Islam promotes harmonious coexistence and advocates a reliance on God (Tawakkul) as a stress-coping strategy (Bonab and Koohsar 2011; Brion-Meisels and Brion-Meisels 2012). Research has suggested that even priming Christians with Buddhist values can also inspire prosocial behaviors such as generosity and tolerance (Clobert and Saroglou 2013). Similarly, research participants primed with Christian values demonstrated greater prosocial characteristics and achieved greater joint-gains in two economic games (namely, the Dictator Game and the Prisoner's Dilemma Game) than participants in the control group (Ahmed and Salas 2011). Thus, negotiators use negotiations as a communicative process to achieve their goals and as an expression of their beliefs and values.

\subsection{Second Element (the Goals): What Do I Need from the Other Party?}

Goals-plans-action theory takes the post-positivist paradigm and posits a single objective reality. Message producers use goals-plans-action theory to manage their interpersonal relationships and plan their messages in a linear fashion, "What is my primary goal? What are my secondary goals?" Message producers first identify what their primary goals are and they then consider possible secondary goals (Dillard and Schrader 1998). Whether message producers will achieve their secondary goals depends upon the message receivers' perception. If message producers believe that they cannot achieve their secondary goals, they may adjust the message and/or their respective primary goals. After message producers have presented their message, the ensuing dialogue will allow the message producer and message receiver to exchange selective information and create a context of shared meaning. Thus, goals-plans-action theory develops interpersonal communication between relational partners and embraces the notion that communication is socially constructed and constitutive.

Goals-plans-action theory is a versatile communication theory. The importance of goals and the varying significance between primary and secondary goals have led to research in message design and production (Samp and Solomon 2005). Scholars have applied this theory to contexts such as instructor-student interactions about disappointing grades (Henningsen et al. 2011), whistleblowing of academic misconduct (Henningsen et al. 2013), action-based pedagogy (Gan 2014), physician-patient communication (Sabee et al. 2012), and discussions on sexual issues between heterosexual spouses (Coffelt and Hess 2015).

\subsection{Third Element (the Plan/s): How Do I Build a Relationship?}

Management scholars noted a dearth of research on attachment orientation's influence on negotiation performance and information sharing (Bear and Segel-Karpas 2015). Individuals who attribute perceived threat in competitive and potentially confrontational situations—such as a purely distributive bargaining encounter, for instance-will more likely experience attachment anxiety and seek avoidance (Almakias and Weiss 2012; Bear and Segel-Karpas 2015). Attachment anxiety among negotiators usually results in moral disengagement or unethical decision-making (Chugh et al. 2014; Lee and Thompson 2011).

Attachment theory provides insights into enduring relationship-building patterns (Almakias and Weiss 2012), especially ongoing and long-term relationships (Bear and Segel-Karpas 2015). VBM 
draws lessons from the way believers of Abrahamic religions view their conceptions of God and eschatology. In broad strokes, believers of Abrahamic religions long for a God who will eventually correct all wrongs and injustices. As those believers wait for the end times, believers of Abrahamic religions assume human agency and seek shalom (or peace) on earth through peacemaking. Other belief systems, in a similar fashion, adopt a social exchange system that develops reciprocal altruism (Kirkpatrick 2012). Consistent with scholarship presented earlier, most people have intrinsic and/or extrinsic reasons for exhibiting prosocial behaviors and for cultivating peaceful relationships.

\subsection{Fourth Element (the Action): How Do I Appeal to the Other Party's Goodness and Remain True to My Values?}

Attribution theory grounds the final element. Although negotiators generally know that all parties want something out of the negotiation, negotiators do not typically create outcomes that benefit all parties (Olekalns and Smith 2013). Since most people care about the outcome, negotiators should begin the dialogue by identifying each other's goals in search of a better outcome.

Before negotiators decide on how they will approach the negotiation, they should return to their belief systems as these values inform human psychology and perceptions. Individuals evaluate their values when they reflect deeply and critically on their religious beliefs (Miner 2008). Negotiators should recognize (not necessarily accept) the professed truths in other belief systems and communicate to (not necessarily persuasively manipulate) an audience "that makes clear distinctions between faith and knowledge" (Hewitt 2008, p. 72). In reality, however, it remains a huge question whether individuals feel secure enough in their own beliefs to explore others' perceptions (Luyten and Corveleyn 2008). Regardless, because everyone views the world through his or her own religious lens (Promta 2010), in a very practical sense, understanding each other's values is the challenge in negotiating a subjectively and objectively superior outcome.

Consider a practical, real-life example to highlight the application of attribution theory's emphasis on causality to conflict management. Marketer-engineer conflict is one of the most well-known, relationship-based conflicts (Keaveney 2008). These two professions serve interdependent functions that are crucial to the productivity and profitability of their companies. Personal differences are at the heart of relationship-based conflicts, such as those between engineers and marketers (Keaveney 2008). VBM posits that personal differences develop from the values that one espouses. Since personal differences can manifest themselves in professional contexts, enshrined values provide a window into how negotiators negotiate as well as their perceptions of reality. Those values that one holds dear ultimately shape what one will seek to confirm or see in real life.

\section{Limitations of and Future Directions for VBM}

Every scholarly endeavor has limitations, which provide possible future directions. Excessive priming of negotiators with values drawn from religious tenets may make them intolerant of ambiguity, which may perpetuate ethnocentrism (Sagioglou and Forstmann 2013). Ethnocentrism brings to the fore negative stereotypes that can lead to egocentrism, which hinders negotiations (Chambers and De Dreu 2014). Because conflicts embody an ambiguous entanglement of interests, negotiators who are intolerant of ambiguity perpetuate the gridlock-intolerance does not help conflict management. Therefore, future studies can extend the utility of VBM by identifying the optimum amount of priming of one's negotiation counterpart/s.

Another major limitation of VBM is that the lack of empirical testing limits the promise of VBM. As a conceptual model, the theories undergirding VBM hang together nicely; empirical validation is the next step to realize the utility and practicality of this model. Future studies can test VBM in several ways. First, researchers can examine how VBM compares with other negotiation models (such as principled negotiation) under experimental conditions. Participants should receive adequate training prior to the experiments, so that they understand how VBM and the comparative model/s work. Undergraduate or graduate students taking courses in negotiations or conflict management are ideal 
candidates because of their familiarity with foundational materials surrounding integrative negotiation and distributive bargaining. Second, researchers can also test VBM using qualitative methods. For instance, researchers may coach participants in VBM and ask participants to comment on whether VBM makes practical sense if they were to apply it to personal and/or professional encounters with which they are familiar. Researchers can also encourage participants to use VBM in real-life situations and to journal their reflections in a diary that they will share with the researchers at a later interview or focus group. Ways to empirically test VBM abound because of its novelty and parsimonious steps. I invite interested researchers on this endeavor.

\section{Practical Considerations, Implications, and Applications of VBM}

Negotiators who look into belief systems in hopes of teasing out the best in their counterparts might encounter three potential issues. First, individuals who dwell in their belief systems may develop a sense of self-righteousness that makes them feel an inflated sense of power. This inflated sense of power gives them a false sense of confidence that boosts their self-concept-a result of their not incorporating social comparison information in their sense-making of reality (Johnson and Lammers 2012). This false sense of confidence creates an optimism bias, which fosters an unrealistic expectation of a distributive outcome at best and encourages bullying at worst. This issue alludes to a rich area of research that intersects cognitive science, communication arts, cultural anthropology, and the psychology of religion.

Second, one can argue that appealing to other people's goodness may appear as underhand manipulation. However, one should balance that criticism and recognize that VBM recommends that negotiators appeal to the other party's goodness and remain true to their own values. This means that negotiators manipulate to the extent that their conscience will allow.

Third, integrative negotiation in general and VBM in particular cannot solve every problem. Negotiators may realize that negotiations alone might not serve their and their constituents' best interests. Some conflicts do fall outside the confines of negotiations. For instance, events such as hit-and-run accidents and criminal assaults fall within the jurisdiction of local authorities who should step in in the public's interest. In such situations, interested parties should seek specialized counsel.

The theoretical contribution of VBM is that it offers a novel way of synthesizing the theses of three communication and psychology theories as a negotiation model anchored in personal values. VBM's practical implication is that it allows negotiators to apply familiar resources (that is, their personal values) to interactions that matter to them. By doing so, they alleviate feelings (such as attachment anxiety) that can negatively affect the negotiation process and outcome; anxious negotiators will likely give up more value than they should because they fear rejection (Almakias and Weiss 2012). In turn, VBM negotiators avert the tendency of defaulting to the avoidance style. This attempt at priming negotiators with attachment security has real-world implication of challenging unethical decision-making that has pervaded much of today's society (Chugh et al. 2014).

\section{Conclusions}

The Buberian principle of I-Thou profoundly promotes the ideals of integrative negotiation and yields the outcomes of distributive tactics. VBM values relationships at and beyond the bargaining table because prosocial behavior serves as negotiation lubricant. While religion is not the only doctrinal source that promotes prosocial behavior, linking religious tenets to distributive bargaining and integrative negotiation makes I-Thou less abstract and more practical in relationship-building and values-based negotiations. As stated before, religion (or the lack thereof) explains human behavior (Proudfoot and Shaver 1975). If religion causes conflicts, it can also contribute to conflict management. Regardless of faith backgrounds, negotiators can profit from VBM's framework of prosocial behavior by negotiating in a way that is consistent with their personal values (Benjamin 1998) while claiming as much value as they can without compromising on their conscience. 
Acknowledgments: The author thanks the editors and peer reviewers for their constructive guidance. Special thanks to Kevin Barge and Mark Young for comments on early drafts of this article.

Conflicts of Interest: The author declares no conflict of interest.

\section{References}

Adler, Robert S., Benson Rosen, and Elliot M. Silverstein. 1998. Emotions in Negotiation: How to Manage Fear and Anger. Negotiation Journal 14: 161-79. [CrossRef]

Ahmed, Ali M., and Osvaldo Salas. 2011. Implicit Influences of Christian Religious Representations on Dictator and Prisoner's Dilemma Game Decisions. The Journal of Socio-Economics 40: 242-46. [CrossRef]

Almakias, Shaul, and Avi Weiss. 2012. Ultimatum Game Behavior in Light of Attachment Theory. Journal of Economic Psychology 33: 515-26. [CrossRef]

Ariely, Dan. 2008. Predictably Irrational. New York: HarperCollins.

Ashwell, Douglas. 2003. The Bargain Exercise. Business Communication Quarterly 66: 68-74. [CrossRef]

Banerjee, Konika, and Paul Bloom. 2013. Would Tarzan Believe in God? Conditions for the Emergence of Religious Belief. Trends in Cognitive Sciences 17: 7-8. [CrossRef] [PubMed]

Barry, Bruce, and Ingrid Smithey Fulmer. 2004. Methodological Challenges in the Study of Negotiator Affect. International Negotiation 9: 485-502. [CrossRef]

Bass, Bernard. M., and Ruth Bass. 2008. The Bass Handbook of Leadership: Theory, Research, and Managerial Applications, 4th ed. New York: Free Press.

Bear, Julia B., and Dikla Segel-Karpas. 2015. Effects of Attachment Anxiety and Avoidance on Negotiation Propensity and Performance. Negotiation and Conflict Management Research 8: 153-73. [CrossRef]

Bechara, Antoine. 2004. The Role of Emotion in Decision-Making: Evidence from Neurological Patients with Orbitofrontal Damage. Brain and Cognition 55: 30-40. [CrossRef] [PubMed]

Benjamin, Robert. D. 1998. Negotiation and Evil: The Sources of Religious and Moral Resistance to the Settlement of Conflicts. Mediation Quarterly 15: 245-66. [CrossRef]

Bonab, Bagher Ghobari, and Ali Akbar Haddadi Koohsar. 2011. Reliance on God as a Core Construct of Islamic Psychology. Procedia-Social and Behavioral Science 30: 216-20. [CrossRef]

Bretfeld, Sven. 2012. Resonant Paradigms in the Study of Religions and the Emergence of Theravāda Buddhism. Religion 42: 273-97. [CrossRef]

Brion-Meisels, Linda, and Steven Brion-Meisels. 2012. Peace Education across Cultures: Applications of the Peaceable Schools Framework in the West Bank. Peace \& Change 37: 572-600. [CrossRef]

Buber, Martin. 1952. Eclipse of God: Studies in the Relation between Religion and Philosophy. Atlantic Highlands: Humanities Press International.

Buber, Martin. 1958. I and Thou, 2nd ed. New York: Charles Scribner's Sons.

Bush, Robert A. Baruch, and Joseph P. Folger. 2005. The Promise of Mediation: The Transformative Approach to Conflict. San Francisco: Jossey-Bass.

Cameron, C. Daryl, B. Keith Payne, and John M. Doris. 2013. Morality in High Definition: Emotion Differentiation Calibrates the Influence of Incidental Disgust on Moral Judgments. Journal of Experimental Social Psychology 49: 719-25. [CrossRef]

Chambers, John R., and Carsten K. W. De Dreu. 2014. Egocentrism Drives Misunderstanding in Conflict and Negotiation. Journal of Experimental Social Psychology 51: 15-26. [CrossRef]

Chugh, Dolly, Mary C. Kern, Zhu Zhu, and Sujin Lee. 2014. Withstanding Moral Disengagement: Attachment Security as an Ethical Intervention. Journal of Experimental Social Psychology 51: 88-93. [CrossRef]

Churchland, Patricia Smith. 2008. The Impact of Neuroscience on Philosophy. Neuron 60: 409-11. [CrossRef] [PubMed]

Clobert, Magali, and Vassilis Saroglou. 2013. Intercultural Non-Conscious Influences: Prosocial Effects of Buddhist Priming on Westerners of Christian Tradition. International Journal of Intercultural Relations 37: 459-66. [CrossRef]

Coffelt, Tina A., and Jon A. Hess. 2015. Sexual Goals-Plans-Actions: Toward a Sexual Script in Marriage. Communication Quarterly 63: 221-38. [CrossRef] 
Colzato, Lorenza S., Ilja van Beest, Wery P. M. van den Wildenberg, Claudia Scorolli, Shirley Dorchin, Nachshon Meiran, Anna M. Borghi, and Bernhard Hommel. 2010. God: Do I Have Your Attention? Cognition 117: 87-94. [CrossRef] [PubMed]

Crilly, Donal, Na Ni, and Yuwei Jiang. 2016. Do-No-Harm versus Do-Good Social Responsibility: Attributional Thinking and the Liability of Foreignness. Strategic Management Journal 37: 1316-29. [CrossRef]

Curhan, Jared R., Hillary Anger Elfenbein, and Heng Xu. 2006. What Do People Value When They Negotiate? Mapping the Domain of Subjective Value in Negotiation. Journal of Personality and Social Psychology 91: 493-512. [CrossRef] [PubMed]

Damasio, Antonio, and Gil B. Carvalho. 2013. The Nature of Feelings: Evolutionary and Neurobiological Origins. Nature Reviews Neuroscience 14: 143-52. [CrossRef] [PubMed]

Der Foo, Maw, Hillary Anger Elfenbein, Hwee Hoon Tan, and Voon Chuan Aik. 2004. Emotional Intelligence and Negotiation: The Tension between Creating and Claiming Value. International Journal of Conflict Management 15: 411-29. [CrossRef]

Dillard, James Price, and David C. Schrader. 1998. Reply: On the Utility of the Goals-Plans-Action Sequence. Communication Studies 49: 300-4. [CrossRef]

Ennis, Leslie Sturdivant. 2008. The Inevitability of Conflict and the Importance of its Resolution in Christian Higher Education. Christian Higher Education 7: 339-56. [CrossRef]

Farias, Miguel, Anna-Kaisa Newheiser, Guy Kahane, and Zoe de Toledo. 2013. Scientific Faith: Belief in Science Increases in the Face of Stress and Existential Anxiety. Journal of Experimental Social Psychology 49: 1210-13. [CrossRef] [PubMed]

Fisher, Roger, and William Ury. 1981. Getting to Yes: Negotiating Agreement without Giving in. Boston: Houghton Mifflin.

Flannelly, Kevin. J., and Kathleen Galek. 2010. Religion, Evolution, and Mental Health: Attachment Theory and ETAS Theory. Journal of Religion and Health 49: 337-50. [CrossRef] [PubMed]

Gan, Ivan. 2014. Teaching Goals-Plans-Action Theory through a Negotiation Exercise. Communication Teacher 28: 246-52. [CrossRef]

Gervais, Will M., and Ara Norenzayan. 2012. Like a Camera in the Sky? Thinking about God Increases Public Self-Awareness and Socially Desirable Responding. Journal of Experimental Social Psychology 48: 298-302. [CrossRef]

Goodwin, Geoffrey P., and John M. Darley. 2008. The Psychology of Meta-Ethics: Exploring Objectivism. Cognition 106: 1339-66. [CrossRef] [PubMed]

Goodwin, Geoffrey P., and John M. Darley. 2012. Why are Some Moral Beliefs Perceived to be More Objective Than Others? Journal of Experimental Social Psychology 48: 250-56. [CrossRef]

Greco, Marco, Antonio Maurizio Branca, and Gianfranco Morena. 2011. An Experimental Study of the Reputation Mechanism in a Business Game. Simulation \& Gaming 42: 27-42. [CrossRef]

Harinck, Fieke, and Gerben A. Van Kleef. 2012. Be Hard on the Interests and Soft on the Values: Conflict Issue Moderates the Effects of Anger in Negotiations. British Journal of Social Psychology 51: 741-52. [CrossRef] [PubMed]

Henningsen, Mary Lynn Miller, Kathleen S. Valde, Gregory A. Russell, and Gregory R. Russell. 2011. Student-Faculty Interactions about Disappointing Grades: Application of the Goals-Plans-Actions Model and the Theory of Planned Behavior. Communication Education 60: 174-90. [CrossRef]

Henningsen, Mary Lynn Miller, Kathleen S. Valde, and Jessica Denbow. 2013. Academic Misconduct: A Goals-Plans-Action Approach to Peer Confrontation and Whistle-Blowing. Communication Education 62: 148-68. [CrossRef]

Hewitt, Marsha A. 2008. Attachment Theory, Religious Beliefs, and the Limits of Reason. Pastoral Psychology 57: 65-75. [CrossRef]

Hicks, Joshua A., and Laura A. King. 2008. Religious Commitment and Positive Mood as Information about Meaning in Life. Journal of Research in Personality 42: 43-57. [CrossRef]

Hillebrandt, Annika, and Laurie J. Barclay. 2017. Comparing Integral and Incidental Emotions: Testing Insights from Emotions as Social Information Theory and Attribution Theory. Journal of Applied Psychology 102: 732-52. [CrossRef] [PubMed]

Johnson, Camille S., and Joris Lammers. 2012. The Powerful Disregard Social Comparison Information. Journal of Experimental Social Psychology 48: 329-34. [CrossRef] 
Jong, Jonathan, Jamin Halberstadt, and Matthias Bluemke. 2012. Foxhole Atheism, Revisited: The Effects of Mortality Salience on Explicit and Implicit Religious Belief. Journal of Experimental Social Psychology 48: 983-89. [CrossRef]

Keaveney, Susan M. 2008. The Blame Game: An Attribution Theory Approach to Marketer-Engineer Conflict in High-Technology Companies. Industrial Marketing Management 37: 653-63. [CrossRef]

Kilmann, Ralph H., and Kenneth W. Thomas. 1977. Developing a Forced-Choice Measure of Conflict-Handling Behavior: The "Mode" Instrument. Educational and Psychological Measurement 37: 309-25. [CrossRef]

Kirkpatrick, Lee A. 2012. Attachment Theory and the Evolutionary Psychology of Religion. The International Journal for the Psychology of Religion 22: 231-41. [CrossRef]

Kuttner, Ran. 2012. Cultivating Dialogue: From Fragmentation to Relationality in Conflict Interaction. Negotiation Journal 28: 315-35. [CrossRef]

Laurin, Kristin, Aaron C. Kay, and David Moscovitch. 2008. On the Belief in God: Towards an Understanding of the Emotional Substrates of Compensatory Control. Journal of Experimental Social Psychology 44: 1559-62. [CrossRef]

Lee, Daniel B. 2009. Communicating Minds: Subjectivity, Objectivity, and Understanding. Studies in Communication Sciences 9: 17-49.

Lee, Sujin, and Leigh Thompson. 2011. Do Agents Negotiate for the Best (or Worst) Interest of Principals? Secure, Anxious and Avoidant Principal-Agent Attachment. Journal of Experimental Social Psychology 47: 681-84. [CrossRef]

Leon-Perez, Jose M., Francisco J. Medina, and Lourdes Munduate. 2010. Effects of Self-Efficacy on Objective and Subjective Outcomes in Transactions and Disputes. International Journal of Conflict Management 22: 170-89. [CrossRef]

Lewicki, Roy J., David M. Saunders, and Bruce Barry. 2015. Negotiation, 7th ed. New York: McGraw-Hill.

Luyten, Patrick, and Jozef Corveleyn. 2008. Attachment and Religion: The Need to Leave Our Secure Base: A Comment on the Discussion between Granqvist, Rizzuto, and Wulff. International Journal for the Psychology of Religion 17: 81-97. [CrossRef]

Mallery, Paul, Suzanne Mallery, and Richard Gorsuch. 2000. A Preliminary Taxonomy of Attributions to God. The International Journal for the Psychology of Religion 10: 135-56. [CrossRef]

Martinko, Mark J., Scott C. Douglas, and Paul Harvey. 2006. Attribution Theory in Industrial and Organizational Psychology: A Review. International Review of Industrial and Organizational Psychology 21: 127-87. [CrossRef]

McCormick, Cornelia, Elisa Ciaramelli, Flavia De Luca, and Eleanor A. Maguire. 2017. Comparing and Contrasting the Cognitive Effects of Hippocampal and Ventromedial Prefrontal Cortex Damage: A Review of Human Lesion Studies. Neuroscience. in press. [CrossRef] [PubMed]

Miner, Maureen H. 2008. Healthy Questing and Mature Religious Reflection: Critique, Antecedents, and Relevance of Attachment Theory? Journal of Psychology of Theology 36: 222-33.

Northouse, Peter Guy. 2015. Introduction to Leadership, 3rd ed. Thousand Oaks: Sage.

Oh, Jo K., and Crystal I. C. Farh. 2017. An Emotional Process Theory of How Subordinates Appraise, Experience, and Respond to Abusive Supervision Over Time. Academy of Management Review 42: 207-32. [CrossRef]

Olekalns, Mara, and Philip Leigh Smith. 2013. Dyadic Power Profiles: Power-Contingent Strategies for Value Creation in Negotiation. Human Communication Research 39: 3-20. [CrossRef]

Ome, Blessing N. 2013. Personality and Gender Differences in Preference for Conflict Resolution Styles. Gender and Behavior 11: 5512-24.

Promta, Somparn. 2010. The View of Buddhism on Other Religions. The Muslim World 100: 302-20. [CrossRef]

Proudfoot, Wayne, and Phillip Shaver. 1975. Attribution Theory and the Psychology of Religion. Journal for the Scientific Study of Religion 14: 317-30. [CrossRef]

Purzycki, Benjamin Grant. 2013. The Minds of Gods: A Comparative Study of Supernatural Agency. Cognition 129: 163-79. [CrossRef] [PubMed]

Reb, Jochen. 2010. The Influence of Past Negotiations on Negotiation Counterpart Preferences. Group Decision and Negotiation 19: 457-77. [CrossRef]

Reinert, Duane F., Carla E. Edwards, and Rebecca R. Hendrix. 2009. Attachment Theory and Religiosity: A Summary of Empirical Research with Implications for Counseling Christian Clients. Counseling and Values 53: 112-25. [CrossRef] 
Robinson, Jennifer, Marta Sinclair, Jutta Tobias, and Ellen Choi. 2017. More Dynamic Than You Think: Hidden Aspects of Decision-Making. Administrative Sciences 7: 23. [CrossRef]

Rubin, Jeffrey. Z., and Walter C. Swap. 1994. Small Group Theory: Forming Consensus through Group Processes. In International Multilateral Negotiation. Edited by I. William Zareman. San Francisco: Jossey-Bass, pp. 132-38.

Sabee, Christina M., Carma L. Bylund, Jennifer Gueguen Weber, and Ellen Sonet. 2012. The Association of Patients' Primary Interaction Goals with Attributions for Their Doctors' Responses in Conversations about Online Health Research. Journal of Applied Communication Research 40: 271-88. [CrossRef]

Sagioglou, Christina, and Matthias Forstmann. 2013. Activating Christian Religious Concepts Increases Intolerance of Ambiguity and Judgment Certainty. Journal of Experimental Social Psychology 49: 933-39. [CrossRef]

Samp, Jennifer A., and Denise Haunani Solomon. 2005. Toward a Theoretical Account of Goal Characteristics in Micro-Level Message Features. Communication Monographs 72: 22-45. [CrossRef]

Shakun, Melvin F. 2006. Spiritual Rationality: Integrating Faith-Based and Secular-Based Problem Solving and Negotiation as Systems Design for Right Action. Group Decision and Negotiation 15: 1-19. [CrossRef]

Shariff, Azim F., and Ara Norenzayan. 2007. God is Watching You: Priming God Concepts Increases Prosocial Behavior in an Anonymous Economic Game. Psychological Science 18: 803-9. [CrossRef] [PubMed]

Spilka, Bernard, and Greg Schmidt. 1983. General Attribution Theory for the Psychology of Religion: The Influence of Event-Character on Attributions to God. Journal for the Scientific Study of Religion 22: 326-39. [CrossRef]

Spilka, Bernard, Phillip Shaver, and Lee A. Kirkpatrick. 1985. A General Attribution Theory for the Psychology of Religion. Journal for the Scientific Study of Religion 24: 1-20. [CrossRef]

Stewart, John, Karen E. Zediker, and Laura Black. 2004. Relationships among Philosophies of Dialogue. In Dialogue: Theorizing Difference in Communication Studies. Edited by Rob Anderson, Leslie A. Baxter and Kenneth N. Cissna. Thousand Oaks: Sage, pp. 21-38.

Stroope, Samuel, Scott Draper, and Andrew L. Whitehead. 2013. Images of a Loving God and Sense of Meaning in Life. Social Indicators Research 111: 25-44. [CrossRef]

Taves, Ann. 2008. Ascription, Attribution, and Cognition in the Study of Experiences Deemed Religious. Religion 38: 126-40. [CrossRef]

Tzafrir, Shay S., Rudolph Joseph Sanchez, and Keren Tirosh-Unger. 2012. Social Motives and Trust: Implications for Joint Gains in Negotiations. Group Decision and Negotiation 21: 839-62. [CrossRef]

Van Kleef, Gerben A., Carsten K. W. De Dreu, Davide Pietroni, and Antony S. R. Manstead. 2006. Power and Emotion in Negotiation: Power Moderates the Interpersonal Effects of Anger and Happiness on Concession Making. European Journal of Social Psychology 36: 557-81. [CrossRef]

Weiner, Bernard. 1985. An Attributional Theory of Achievement Motivation and Emotion. Psychological Review 92: 548-73. [CrossRef] [PubMed]

Willard, Aiyana K., and Ara Norenzayan. 2013. Cognitive Biases Explain Religious Belief, Paranormal Belief, and Belief in Life's Purpose. Cognition 129: 379-91. [CrossRef] [PubMed]

Xie, Tian, and Jing Zhou. 2012. Feelings and Comparisons in Negotiation: One Subjective Outcome, Two Different Mechanisms. Public Personnel Management 41: 21-33. [CrossRef]

Young, Liane, and A. J. Durwin. 2013. Moral Realism as Moral Motivation: The Impact of Meta-Ethics on Everyday Decision-Making. Journal of Experimental Social Psychology 49: 302-06. [CrossRef]

(C) 2017 by the author. Licensee MDPI, Basel, Switzerland. This article is an open access article distributed under the terms and conditions of the Creative Commons Attribution (CC BY) license (http:/ / creativecommons.org/licenses/by/4.0/). 